\title{
СЖАТИЕ ОСВОЕННОГО ПРОСТРАНСТВА В ЦЕНТРАЛЬНОЙ РОССИИ: ДИНАМИКА НАСЕЛЕНИЯ И ИСПОЛЬЗОВАНИЕ ЗЕМЕЛЬ В СЕЛЬСКОЙ МЕСТНОСТИ
}

\author{
(C) 2020 г. Т. Г. Нефедова ${ }^{a,}$ *, А. А. Медведев ${ }^{a, * *}$ \\ ${ }^{a}$ Институт географии РАН, Москва, Россия \\ *e-mail: trene12@yandex.ru \\ **e-mail:medvedev@igras.ru \\ Поступила в редакцию 17.03.2020 г. \\ После доработки 08.05.2020 г. \\ Принята к публикации 06.06.2020 г.
}

\begin{abstract}
В основе статьи лежит комплексный подход, включающий совместное рассмотрение сокращения традиционного сельскохозяйственного использования земель, увеличения доли малых и заброшенных деревень и расширения новых видов рекреационного использования сельской местности вокруг Москвы и Московской области. Использование в статье статистических показателей по субъектам РФ и муниципальным районам, а также космических снимков дает полимасштабную и дробную картину сжатия использования земель, которое в последние годы все более явно географически повторяет исторический процесс освоения этих территорий, только с обратным знаком. Сельскохозяйственное производство “сдвигается” в районы с лучшими природными условиями, в том числе внутри регионов. Тенденция его концентрации в пригородах, где используются преимущества накопленных инвестиций, трудовые ресурсы, возможности сбыта, обустроенность территории, постепенно меняется на развитие в очагах с лучшими природными предпосылками, порой удаленных от городов. При этом население продолжает концентрироваться в городах и пригородах центров регионов, что способствует сжатию заселенного пространства. Эти разнонаправленные тенденции подтверждаются расчетами по муниципальным районам за период с 1990 по 2017 г. Выводы проиллюстрированы и подтверждены картами на территорию Центральной России, составленными на основе дешифрирования космических снимков. На картах показаны обрабатываемые сельскохозяйственные земли и залежи, а также распространение заброшенных и малых деревень. Расчеты по муниципальным районам на основе информации, полученной по картам, позволяют скорректировать статистические показатели и увидеть реальную картину изменения сельского расселения и использования земель. Картографический метод позволил выявить также возможности и ограничения реосвоения сельских территорий горожанами, включая не только расширяющиеся площади садовых/дачных товариществ и коттеджных поселков, но и дачи горожан в депопулирующих деревнях.
\end{abstract}

Ключевые слова: староосвоенные районы, использование земель, сельское хозяйство, посевные площади, расселение, динамика населения, реосвоение, дачи, дистанционное зондирование, дешифрирование космических снимков, картографический метод

DOI: $10.31857 / \mathrm{S} 258755662005012 \mathrm{X}$

\section{ВВЕДЕНИЕ. ПОСТАНОВКА ЗАДАЧИ}

Сжатие освоенного пространства в последние годы было в поле внимания исследователей [23, 26, 34]. Особенно это касалось сельского населения, сельского хозяйства и землепользования $[1,4,12$, 20]. В новых - рыночных - условиях размещение сельскохозяйственного производства стало в большей степени ориентироваться на качество земельных ресурсов, развитость инфраструктуры и близость к рынкам сбыта, поэтому из оборота выпали в первую очередь удаленные и малоплодородные земли [22, 39, 44]. Однако изменение использования земель могло иметь и более глубокие предпосылки. Территориальное сжатие аграрного производства характерно для большинства развитых стран мира и продиктовано внутренней логикой развития сельского хозяйства, связанной с его интенсификацией [13].

Спад аграрного производства в Нечерноземных регионах в постсоветской России был, фактически, подготовлен депопуляцией сельских территорий в предшествующий период и слишком высокими издержками советской модели сельского хозяйства в этих районах [11]. Транс- 
формация и состояние сельской экономики, особенно сельского хозяйства, резкое уменьшение рабочих мест и стабильных доходов способствовали расслоению районов на более заселенные и экономически успешные - южные, и с тающим населением и большими потерями сельскохозяйственных земель - нечерноземные.

Исследования соотношения динамики использования земель и сельского расселения в европейской части России показывали их тесную связь $[13,21]$. Однако в последние годы в процессах сжатия освоенного пространства наметились изменения. Они особенно заметны в центральных регионах, для которых характерна сильная и неоднозначная трансформация сельского хозяйства и сельской местности. Выбор этих регионов для исследования ${ }^{1}$ был связан также с попытками выявить влияние на сельскую местность Московской агломерации и других крупных городов, которые, с одной стороны, вытягивают население из других территорий, а с другой, служат источниками диффузии экономических инноваций и человеческого капитала. Кроме того, для этой территории характерно разнообразие ландшафтных условий - от таежных лесов на севере до ландшафтов, переходных к лесостепным, на юге. При сжатии сельскохозяйственного землепользования здесь происходила активная модернизации сельского хозяйства и его концентрация в отдельных очагах и ареалах. При этом близость к Москве способствовала расширению рекреационно-дачных очагов, приходящих на смену исчезающим традиционным видам использования земель.

Целью комплексного исследования было выявление пространственных особенностей и соотношения динамики сельского населения и сельскохозяйственного землепользования ${ }^{2}$ в Центральной России, а также определение возможностей рекреационно-дачного реосвоения сельских территорий. Исследование проводилось на разных масштабных уровнях: по областям и муниципальным районам. Использовались данные Росстата, Росреестра, сельскохозяйственных переписей, переписей населения. Однако мелкоконтур-

\footnotetext{
${ }^{1}$ Рассматривались 10 регионов ЦФО, испытывающих сильное влияние Москвы и трансформацию расселения и использования земель: Московская, Смоленская, Тверская, Ярославская, Костромская, Ивановская, Владимирская, Рязанская, Тульская, Калужская области.

2 При анализе статистических показателей в качестве индикатора изменения использования земель в сельском хозяйстве в статье использовался показатель посевной площади, по которому ежегодно Росстат публикует данные по субъектам РФ и муниципальным районам. В регионах Центра России, для которых не характерны значительные площади паров, посевные площади, как правило, меньше площади пашни на 2-5\%. В настоящее время при значительных заброшенных плошадях пашни и пастбищ и их более редком переучете статистические данные по посевным площадям более точно отражают реальные площади используемых в растениеводстве земель.
}

ность использования земель, специфика расселения с обилием малых деревень и несовершенство статистических показателей потребовали более точных методов исследования с использованием космических снимков высокого разрешения.

\section{СПЕЦИФИКА РАССЕЛЕНИЯ \\ И ИСПОЛЬЗОВАНИЯ ЗЕМЕЛЬ В ЦЕНТРАЛЬНОЙ РОССИИ}

В результате демографического перехода, а также изменения соотношения между естественным движением населения и его миграциями, в разных регионах России происходили диаметрально противоположные процессы. Они привели к перераспределению сельского населения между северными и южными регионами и между городами с их пригородами и периферией регионов $[11,19,22]$. Сельскохозяйственное производство также сдвигалось в южные регионы и ближе к пригородам, однако социальные и экономические процессы не были синхронны во времени.

Наибольшие потери сельского населения были характерны для советского времени, несмотря на мощную государственную поддержку малоэффективного сельского хозяйства и включения в оборот земель худшего качества. При уменьшении за 30 последних советских лет сельского населения вдвое, посевная площадь сохранялась (табл. 1, рис. 1, 2). Площади возделывания маргинальных “холодных" земель значительно превышали и до сих пор превышают, хотя и не столь сильно, разумные нормы [8]. С 1990 по 2010 г. соотношение трендов динамики посевных площадей и сельского населения изменилось. Потери земель стали опережать потери сельского населения, особенно в регионах, расположенных к северу от Московской области.

Разнообразие мелкоконтурных угодий и низкое плодородие подходило для мелкого дореволюционного крестьянского хозяйства при избытке сельского населения и его самообеспечении, в том числе благодаря наличию скота как условия выживания домохозяйств и источника удобрения почв. Ни инвестиции, ни мелиорация, ни минеральные удобрения не смогли обеспечить здесь в советское время достаточную эффективность сельского хозяйства, которое держалось в основном на больших дотациях. Изменившиеся стимулы постсоветского развития привели к недееспособности в этих районах советского варианта организации хозяйствования. Но и частные хозяйства здесь не возникали в таком количестве, как на Юге России, из-за истощения трудового потенциала в результате длительной депопуляции.

В результате регионы к северу от Московской области за период чуть более полувека потеряли $60 \%$ сельского населения, в основном в позднесо- 
Таблица 1. Динамика посевных площадей и сельского населения в регионах вокруг Москвы с 1960 по 1990 (1989) и с 1990 (1989) по 2018 г., \%

\begin{tabular}{l|c|c|c|c}
\hline \multirow{2}{*}{\multicolumn{1}{c|}{ Территория }} & \multicolumn{2}{|c|}{ Динамика посевной площади } & \multicolumn{2}{|c}{ Динамика сельского населения } \\
\cline { 2 - 5 } & 1990 к 1960 & 2018 к 1990 & 1989 к 1959 & 2018 к 1989 \\
\hline Московская область (МО) & 105.6 & 47.3 & 66.3 & 101.8 \\
Северо-запад и северо-восток от МО & 104.6 & 32.9 & 47.8 & 73.0 \\
Юг и юго-восток от МО & 103.2 & 50.7 & 50.3 & 82.4 \\
\hline
\end{tabular}

Источники: рассчитано по данным переписей и текущего учета населения.

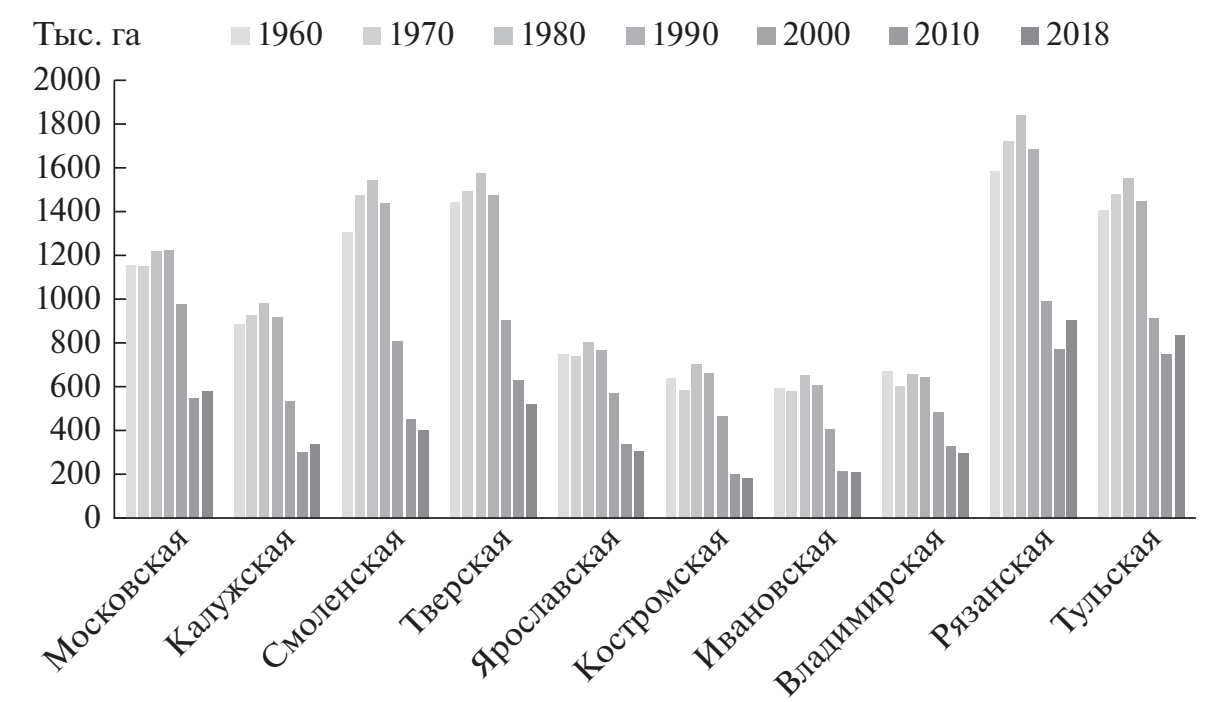

Рис. 1. Изменение посевной площади с 1960 по 2018 г. в Московской области и регионах вокруг нее, тыс. га. Источник: данные Росстата.

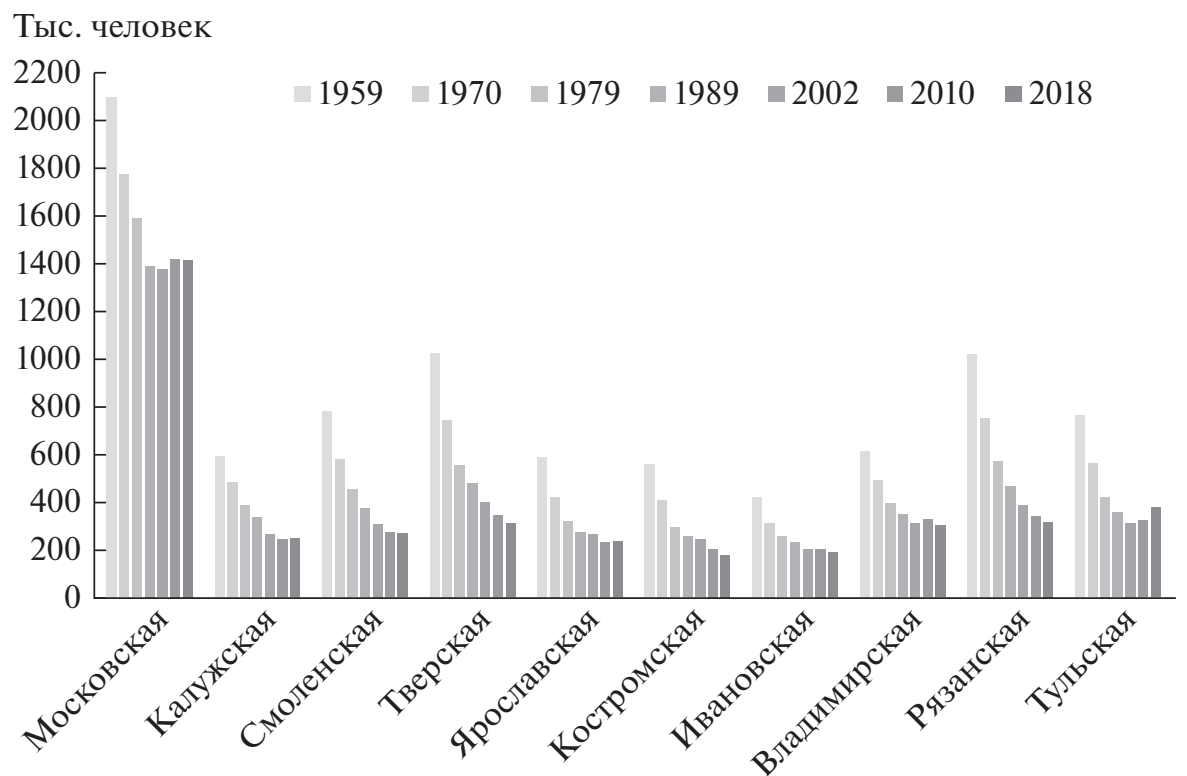

Рис. 2. Изменение численности сельского населения с 1959 по 2018 г. в Московской области и регионах вокруг нее. Источник: данные переписей и текущего учета населения.

ветское время, и 2/3 посевных площадей, в основном после 1990 г. В регионах, расположенных южнее, потери населения были столь же велики, однако сокращение посевных площадей меньше, особенно в Рязанской и Тульской областях. С ними сопоставима динамика использования земель 
в Московской области, несмотря на активно наступающую на сельскохозяйственные земли застройку и увеличение численности населения.

\section{ИЗМЕНЕНИЕ СЕЛЬСКОГО РАССЕЛЕНИЯ И ПОСЕВНЫХ ПЛОЩАДЕЙ ВНУТРИ РЕГИОНОВ}

Главным фактором пространственной организации сельской местности в Центральной России и в советское, и в постсоветское время были пригородно-периферийные различия [11, 21]. Особенно это характерно для плотности сельского населения, которая в результате длительной депопуляции различается в ближайших пригородах больших городов и на периферии регионов на порядок; при этом степень контрастности расселения продолжает увеличиваться (рис. 3,4 ).

В результате сжатия землепользования на разном удалении от областных центров сохранилось от 20 до 50\% посевных площадей от уровня 1990 г. Наибольшие потери характерны для удаленных районов (рис. 5, 6). Однако в отличие от плотности населения современное распределение посевной площади и ее доля в территории муниципальных районов не имеет, кроме окраин, столь ярко выраженных пригородно-периферийных различий.

Для объяснения распределения и динамики посевных площадей в разные отрезки постсоветского периода были рассчитаны корреляционные зависимости показателей с рядом факторов (табл. 2).

Анализ табл. 2 позволяет сделать вывод о росте значимости природных предпосылок в последние годы в процессе трансформации использования

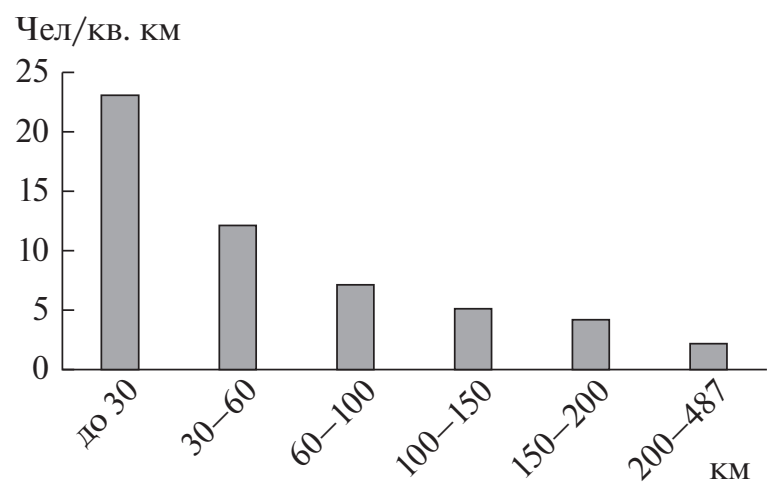

Рис. 3. Плотность сельского населения в муниципальных районах по мере удаления (км) от областного центра в регионах, окружающих Московскую область, 2017 г., чел./кв. км. Рассчитано по данным Росстата. земель. Если в период кризиса 1990-х и в начале 2000-х годов выживаемость предприятий зависела во многом от экономических перемен, то в последние годы стала возрастать роль географических факторов. Освоение и заселение этих территорий шло от ополий, в широком понимании, как территорий с лучшими условиями дренированности, качеством почв, меньшей мелкоконтурностью угодий в менее благоприятные районы, а сжатие землепользования идет в обратном направлении, стягиваясь к опольям. Экспедиционные исследования в ряде регионов показали, что торможение сжатия и даже очаговое сельскохозяйственное реосвоение земель происходит либо ближе к областным центрам и большим городам, либо в очагах с лучшими природными предпосылками. Это подтверждают и рис. 5, 6. Чаще восстановление связано с животноводством для снабжения молоком и мясом Москвы и других городов, в том числе в агрохолдингах [30], но с расширением собственной кормовой базы на месте. Хотя многое зависит от размеров этих очагов, их соотношения, транспортной доступности, включения предприятий в агрохолдинги и даже от личности руководителя. Несмотря на то, что часть крупных агрохолдингов вокруг Московского региона имеет филиалы в южных регионах Европейской России для производства кормов, для рассматриваемых регионов также характерно возвращение части заброшенных земель в оборот, особенно в областях, примыкающих к Московскому региону с юга. Севернее пригородные предприятия чаще продолжают использовать накопленный в советское время инвестиционный потенциал, лучшую

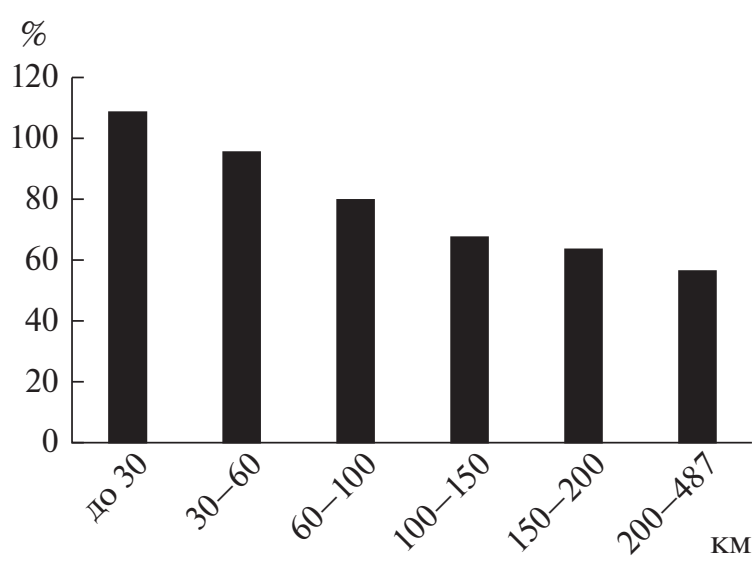

Рис. 4. Динамика сельского населения в муниципальных районах по мере удаления (км) от областного центра в регионах, окружающих Московскую область, 2017 к 1990 г., \%. Рассчитано по данным Росстата. 


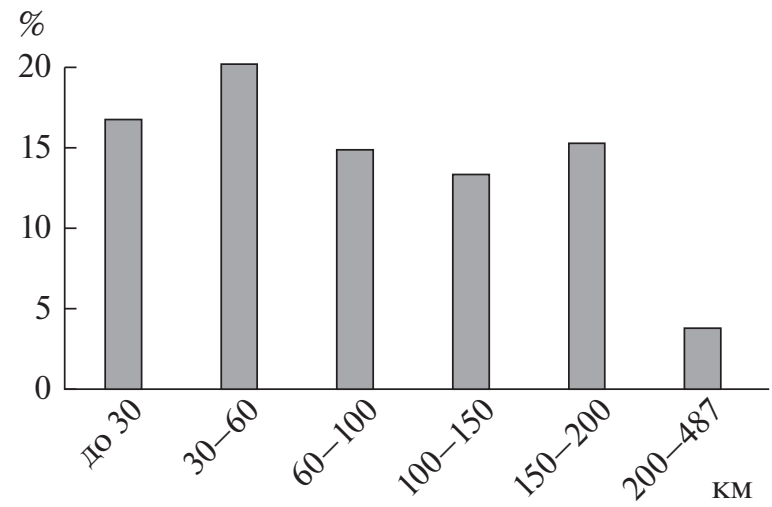

Рис. 5. Доля посевной площади в территории муниципальных районов по мере удаления (км) от областного центра, 2017 г., \%. Рассчитано по данным Росстата.

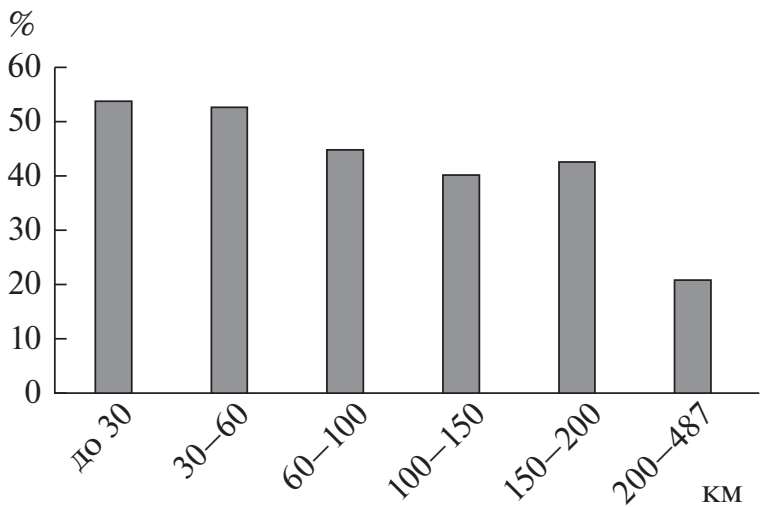

Рис. 6. Динамика посевной площади по мере удаления (км) района от областного центра, 2017 к 1990 г., $\%$. Рассчитано по данным Росстата.

Таблица 2. Корреляционные зависимости изменения посевных площадей с разными факторами в муниципальных районах областей, окружающих Московскую область*

\begin{tabular}{|c|c|c|c|c|c|}
\hline \multirow{2}{*}{ Показатель } & \multicolumn{3}{|c|}{ Динамика посевных площадей } & \multirow{2}{*}{\begin{tabular}{|c|}
$\begin{array}{c}\text { Доля посевной } \\
\text { площади } \\
\text { в территории района }\end{array}$ \\
2017 г.
\end{tabular}} & \multirow{2}{*}{\begin{tabular}{|c}
$\begin{array}{c}\text { Доля зерновых } \\
\text { культур в посевной } \\
\text { площади }\end{array}$ \\
2017 г.
\end{tabular}} \\
\hline & 1990-2000 гг. & $2000-2010$ гг. & 2010-2017 гг. & & \\
\hline Биоклиматический потенциал** & -0.11 & 0.13 & 0.39 & 0.61 & 0.68 \\
\hline $\begin{array}{l}\text { Доля лесов и болот в территории } \\
\text { района }\end{array}$ & 0.06 & -0.31 & -0.44 & -0.85 & -0.78 \\
\hline Расстояние до центра области & -0.16 & -0.14 & -0.23 & -0.29 & -0.15 \\
\hline Плотность сельского населения & 0.27 & 0.29 & 0.14 & 0.37 & 0.27 \\
\hline $\begin{array}{l}\text { Динамика сельского населения } \\
\text { в соответствующий период }\end{array}$ & 0.16 & 0.19 & 0.19 & & \\
\hline
\end{tabular}

*Рассчитано по данным Росстата по 327 муниципальным районам. ** Биоклиматический потенциал определяется как соотношение увлажнения (разницы между суммой осадков и испарением) и суммой температур выше $+10^{\circ} \mathrm{C}$.

инфраструктурную обустроенность и качество человеческих ресурсов.

\section{СОВРЕМЕННОЕ ИСПОЛЬЗОВАНИЕ ЗЕМЕЛЬ ПО ДАННЫМ КОСМИЧЕСКОЙ СЬЕМКИ}

Учитывая сравнительно большую площадь муниципальных единиц в России, по статистическим показателям трудно понять реальную географию изменения использования земель и расселения [36]. Гораздо более точную картину дает использование данных дистанционного зондирования Земли (ДЗ3). Существующие методики картографирования использования земель по данным космических снимков опираются на различия между внутригодовыми и межгодовыми изменениями спектрального отражения возделы- ваемых в сельском хозяйстве земель и соответствующими изменениями для других типов почвеннорастительного покрова на основе многолетних временных рядов данных [6, 32, 33, 37, 39, 40]. Для дифференциации использования земель по сезонам года использовались серии безоблачных снимков Landsat ${ }^{3}$. Весенние снимки показывают территории, которые распахиваются. Летние снимки четко отображают сельскохозяйственные культуры в разных стадиях вегетации, на них при спектральном анализе распознаются поля с гомогенной структурой и высоким вегетационным индексом. Сопоставление с осенними снимками обеспечивает разделение возделываемых участков и залежей. Детальный (как пространственно,

\footnotetext{
${ }^{3}$ Архив Геологической службы США - USGS. http://earthexplorer.usgs.gov/ за период с 2000 по 2014 г.
} 


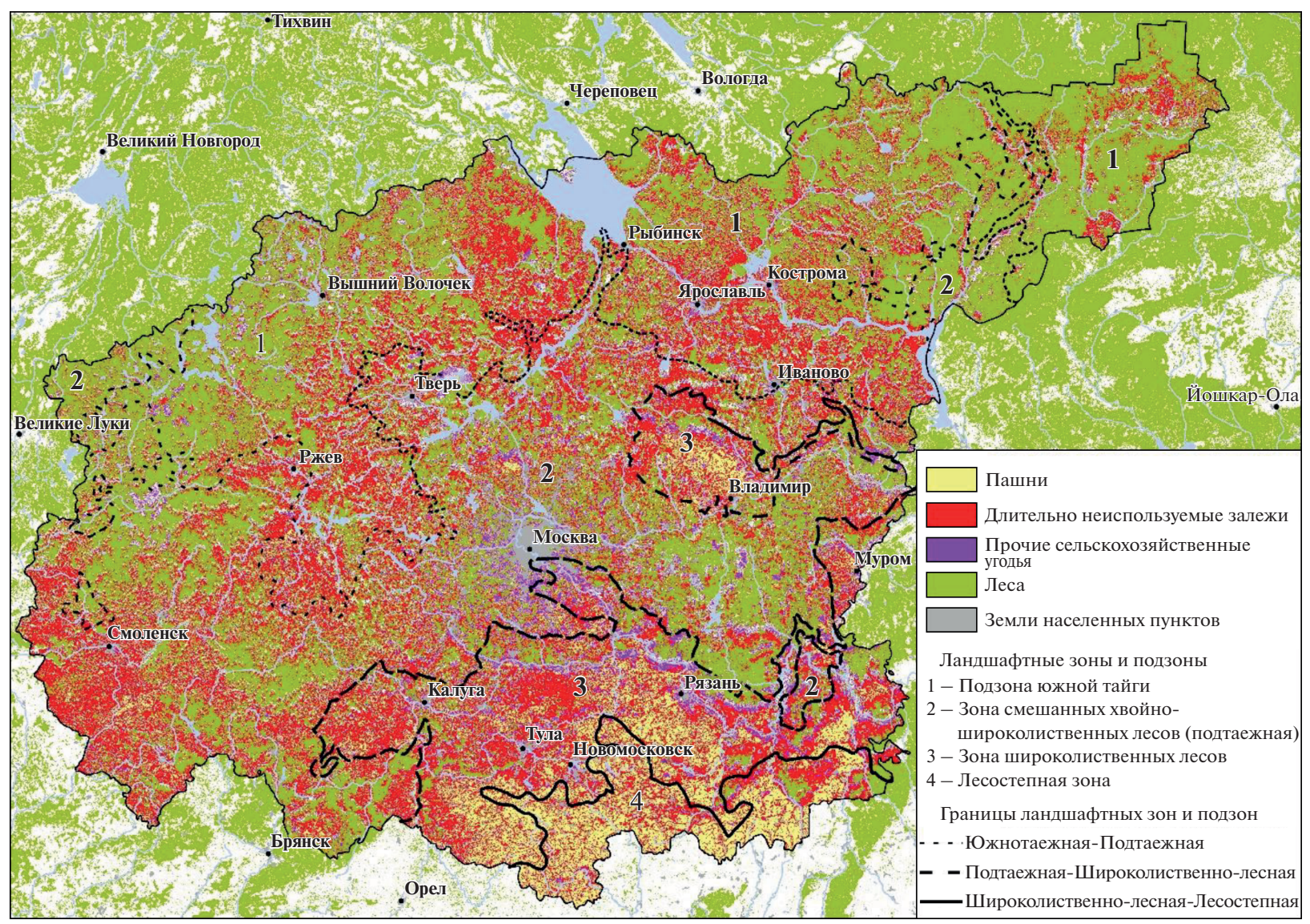

Рис. 7. Используемые и длительно неиспользуемые (залежные) земли в Центральной России с учетом типов ландшафтов. Составлено А.А. Медведевым на основе дешифрирования космических снимков.

так и тематически) набор данных объединялся в единую бесшовную мозаику и содержал подробные данные почвенно-растительного покрова.

Карта, составленная на основе дешифрирования космических снимков на середину 2010-х годов с показом реальных контуров угодий, в целом подтверждает выявленные выше статистически различия в использовании земель (рис. 7). Видна приуроченность забрасывания земель к определенным типам ландшафтов ${ }^{4}$. Наибольшие площади заброшенных сельскохозяйственных земель характерны для удаленных окраинных территорий регионов Нечерноземья, а относительно крупные ареалы засеваемых земель - это, прежде всего, южные районы Тульской, Рязанской и Калужской областей. Выделяется Владимирское ополье, заходящее на юго-восток Ярославской и юго-запад Ивановской областей, хотя и для него характерна высокая вторичная дробность угодий

\footnotetext{
${ }^{4}$ Подробный анализ контуров и степени зарастания заброшенных угодий требует рассмотрения отдельных ключевых участков в более крупном масштабе с привлечением аэрофотоснимков разного времени и планируется в следующей публикации.
}

с мелкими заброшенными участками. Видны очаги и в старых ареалах освоения вокруг Ярославля, Костромы, Ростова, Мурома.

Результаты дистанционного зондирования подтвердили расхождение между реальной ситуацией и официальной статистикой использования земель. Статистические данные по структуре сельскохозяйственных угодий завышают площади пашни и естественных кормовых угодий и занижают площади лесных угодий, которые увеличиваются в последние десятилетия из-за зарастания древесной растительностью заброшенных сельскохозяйственных земель, что подтверждают и другие исследования [17, 35]. Более того, фактически используемые и культивируемые земли меньше не только площади пашни, но и посевных площадей - на 10-40\% от официальных статистических показателей. Особенно это характерно для лесных регионов (Костромской, Ивановской, Тверской областей). А в южных районах Тульской и Рязанской областей в отчетах, наоборот, наблюдается небольшое (до 10\%) занижение реально культивируемых земель. Отчасти это может быть связано с техническими погрешностями, но имеет и свое объяснение. Занижение ре- 
ально используемых площадей может быть выгодно агрохолдингам для снижения налогов. А завышение отчетных показателей в результате отсутствия реальных данных или путем приписок характерно для большинства регионов ${ }^{5}$. На это указывали и другие исследователи, сравнивая данные Росреестра и Сельскохозяйственной переписи 2016 г. [27, 29]. В отличие от советского времени, когда приписки используемых площадей были связаны с требованиями выполнения плановых заданий, сейчас это может объясняться стремлением получить дотации или сохранить видимость сельскохозяйственного использования с тем, чтобы потом переоформить эти земли под застройку или дачи. Последнее особенно характерно для пригородов. Недаром большая доля залежей, выявляемых именно с помощью космических снимков и оформленных как используемые в растениеводстве территории, характерна для ближайших пригородов (до 30 км) ${ }^{6}$.

Масштабы реальных потерь сельскохозяйственных угодий и распределение используемых пахотных земель видны на картах (рис. 8), составленных на основе обобщения данных дешифрирования космических снимков по муниципальным районам.

Меньше всего доля сельскохозяйственных земель и больше доля лесов на северо-западе и северо-востоке рассматриваемого региона (рис. 8а, 8в). Именно для этих районов характерно наиболее быстрое зарастание залежей лесом (рис. 8г). Однако большие площади длительно неиспользуемых залежей и их повышенная доля в площади сельскохозяйственных угодий (рис. 8б) характерна для гораздо более обширной территории Смоленской, Тверской, Ярославской, Ивановской,

\footnotetext{
${ }^{5}$ Федеральные информационные системы (Публичная кадастровая карта Росреестра - https://pkk.rosreestr.ru/ и Информационная система Минсельхоза (ЕФИС ЗСН) http://efis.mcx.ru/) включают сотни и тысячи ошибок. Их источником служат отличия отчетного и фактического использования земель и нарушение необходимых агромероприятий. Росстат периодически заказывает исследования Институту космических исследований РАН для верификации отчетной информации. При Минсельхозе РФ также существует группа, которая занимается проверкой подаваемых региональных данных с использованием космической съемки. Все эти исследования отмечают расхождения с официальной статистикой. Особый вопрос - многолетние травы, которые в нашем исследовании отнесены к залежам, так как на полях не ведется активное хозяйство. Наблюдения в Костромской, Ярославской и Тульской областях показали, что в районах с большим количеством заброшенных земель такие поля на второй-третий год мало отличаются от окружающих залежей.

6 Часть сельскохозяйственных земель в пригородах крупных городов имеют характерный вид - редкая вспашка (раз в несколько лет), наличие гетерогенной структуры растительности, периодическое кошение. Данный набор признаков прежде всего связан с тем, что собственники во избежание штрафов за неиспользование сельскохозяйственных земель проводят периодически агромероприятия, но фактически не используют земли по прямому назначению.
}

частично Московской, Владимирской и Рязанской областей. Сохраняются пахотные земли в районах с благоприятными природными условиями. Эти районы стали самыми перспективными для сохранения и развития сельского хозяйства. К ним добавляются пригороды региональных центров, а также некоторые территории в Московской области. Несмотря на расширяющуюся жилую и дачную застройку и простаивание части сельскохозяйственных земель, накопленный экономический потенциал, инвестиции из городов и огромный спрос делают их самыми динамичными, в том числе и для развития сельского хозяйства. На удаленных территориях, особенно к северу от Москвы, учитывая степень зарастания залежей лесом, надеяться на возвращение земель в оборот не стоит.

\section{ИСПОЛЬЗОВАНИЕ КОСМИЧЕСКИХ СНИМКОВ ДЛЯ ИССЛЕДОВАНИЯ СЕЛЬСКОГО РАССЕЛЕНИЯ}

Главный тренд в структуре расселения советской и постсоветской России - усиление поляризации сельских населенных пунктов: рост числа и доли малых и заброшенных деревень и концентрация населения в крупных селах $[4,7,10,14]$. При этом число средних пунктов уменьшалось быстрее всего, в основном за счет их перехода в группу малых. Последние все чаще переходили в разряд необитаемых.

Анализ заселенности сельской местности также осложняется отсутствием реальных данных о наличном населении в разные периоды. Показатели численности постоянного населения в сельской местности включают население, которое по несколько месяцев живет в городах, и не учитывают городских дачников, увеличивающих население в деревнях в летний сезон в несколько раз [3, 18]. Поэтому и здесь использование космических снимков весьма продуктивно.

Для определения реального сельского расселения, в том числе выявления населенных пунктов без населения, на космических снимках анализировалось состояние сельских домов и окружающей территории. Прямыми и косвенными признаками отсутствия постоянного населения служили разрушенные крыши и строения, заброшенные и зарастающие земли вокруг домов и деревень [16]. Помимо космических снимков сверхвысокого пространственного разрешения использовались статистические и картографические данные (топографические карты масштаба 1 : 100000 и 1 : 200000 , а также материалы публичной кадастровой карты Росреестра, в том числе перечень населенных пунктов). Их совместное использование позволило выявить и показать на картах размещение населенных пунктов без постоянного населения (рис. 9). 
(a)

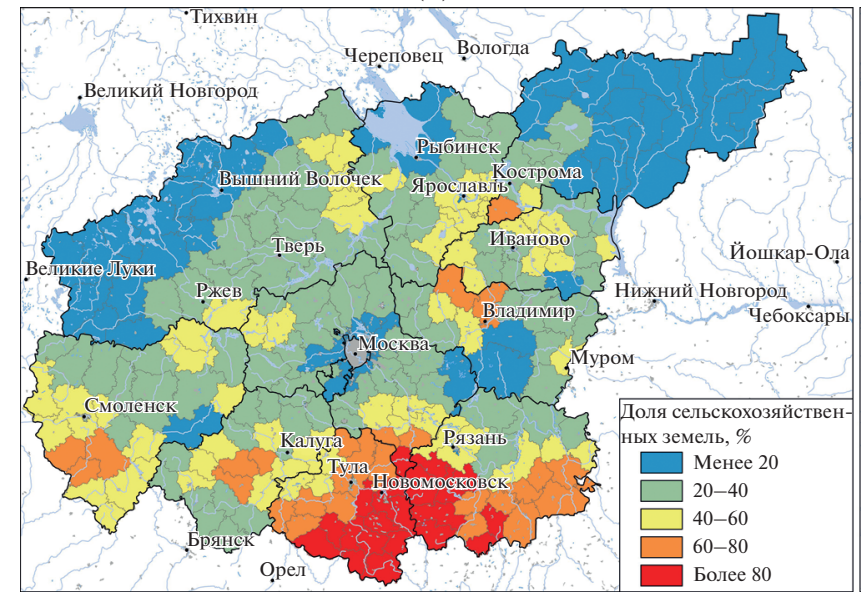

(B)

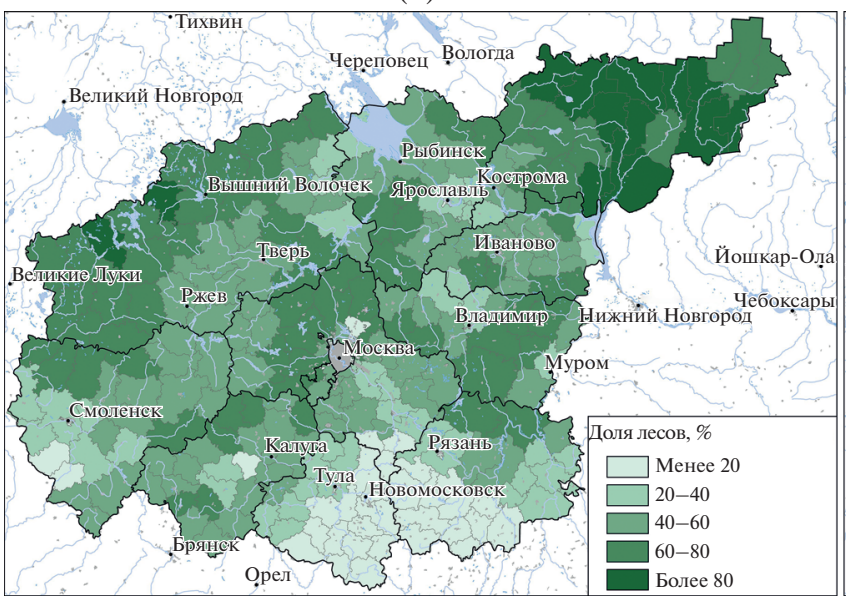

(б)

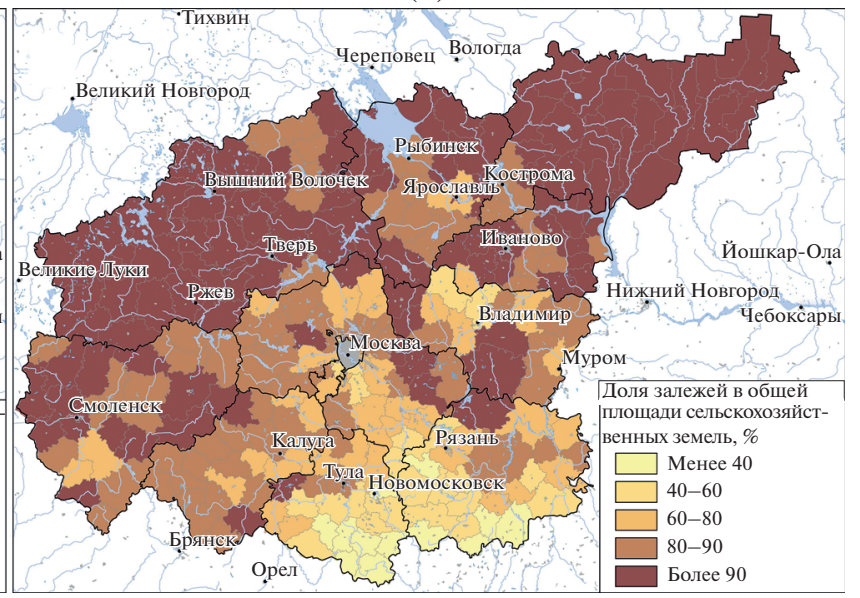

(г)

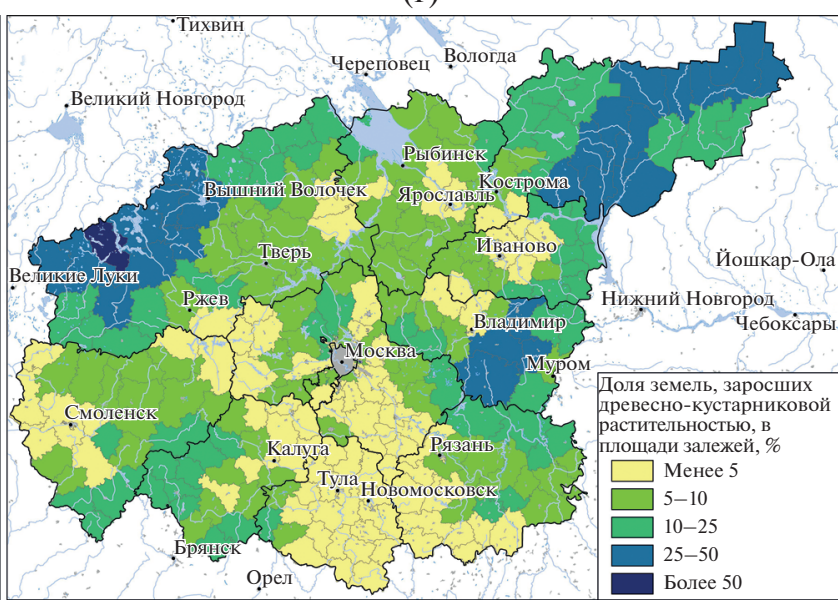

Рис. 8. Современное использование земель по муниципальным районам в Московской области и в регионах, ее окружающих: (а) доля сельскохозяйственных земель, \%; (б) доля залежей в общей площади сельскохозяйственных земель, \%; (в) доля лесов, \%; (г) доля земель, заросших древесно-кустарниковой растительностью, в площади залежей, $\%$. Рассчитано А.А. Медведевым на основе карт, составленных по результатам дешифрирования космических снимков.

Распределение заброшенных населенных пунктов, а также деревень без постоянного населения рассматривались рядом авторов на примере отдельных регионов, в том числе и тех, которые попадают в орбиту нашего исследования, особенно в Тверской области [9, 25, 28]. Материалы Всероссийской переписи населения 2010 г. показывают, что Нечерноземные регионы вокруг Московской области характеризуются большим количеством заброшенных и малых (менее 100 зарегистрированных жителей) деревень (рис. 10). Именно в районах их концентрации характерен наиболее сильный кризис сельскохозяйственных предприятий и сжатие посевных площадей (см. рис. $7,8,9)$. При транспортной доступности такие деревни становятся привлекательными для дачников.

\section{РЕОСВОЕНИЕ СЕЛЬСКИХ ТЕРРИТОРИЙ ГОРОЖАНАМИ-ДАЧНИКАМИ}

В последнее время все больше внимания обращают на отдельные примеры переселения горожан в сельскую местность и организацию там малого бизнеса, в том числе сельскохозяйственного. Они активно обсуждаются в интернете, создавая ложное впечатление массовой дезурбанизации. Однако на фоне оттока населения из сел и деревень это капли в море. С масштабами сельской депопуляции в ряде районов сравним лишь поток горожан в сельскую местность не на постоянное место жительства, а для сезонного отдыха на дачах, в том числе в деревнях. Например, в Костромской области даже на значительном удалении от Москвы во многих малых деревнях число горожан-дачников, в основном москвичей, летом 


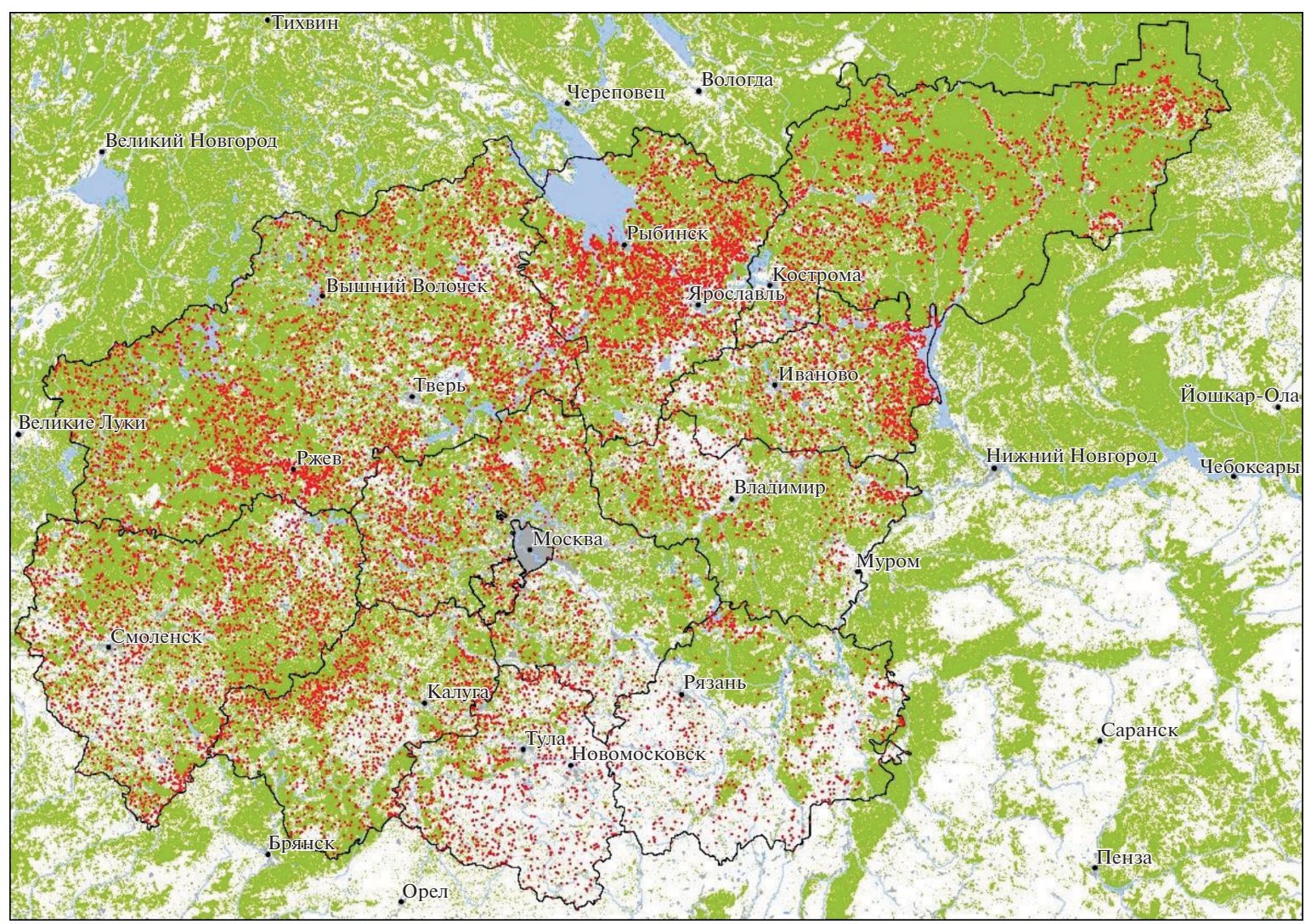

Рис. 9. Нежилые населенные пункты и с отсутствием постоянного населения в Центральной России. Составлено А.А. Медведевым по результатам дешифрирования космических снимков.

превышает число местных жителей $[18 ; 24$, c. 385-419]. Эти процессы характерны не только для России, но и для европейских стран $[35,41]$, особенно для стран с похожими на Нечерноземье природными условиями, например Финляндии [42].

Даже в деревнях без постоянного населения отдельные дома могут в летний сезон использовать “отшельники-дачники”. Однако обследование многих муниципальных районов в регионах Нечерноземья показало, что горожане предпочитают покупать сельские дома для дачного отдыха не в заброшенных, а в живых деревнях, среди которых наиболее популярны небольшие деревни с населением менее 100 чел.

Подробное исследование некоторых удаленных от больших городов нечерноземных районов позволило выделить несколько волн расширения дачного использования деревень горожанами [2]. Первая, романтическая, волна началась в позднесоветское время, когда в деревнях еще присутствовала молодежь и немногочисленные горожане органично вписывались в сельскую жизнь на короткий период отпуска. Вторая, прагматичная, волна характерна для начала 1990-х годов, когда горожане пытались спасти деревню. Некоторые приобретали землю и даже заводили скот. Однако

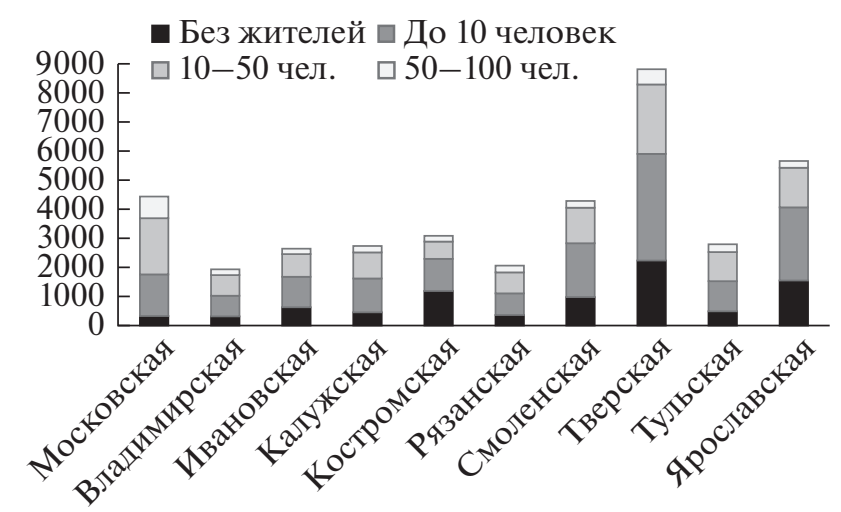

Рис. 10. Число населенных пунктов без жителей и с населением менее 100 человек в регионах Центральной России, 2010 г. По данным Всероссийской переписи населения 2010 г. 


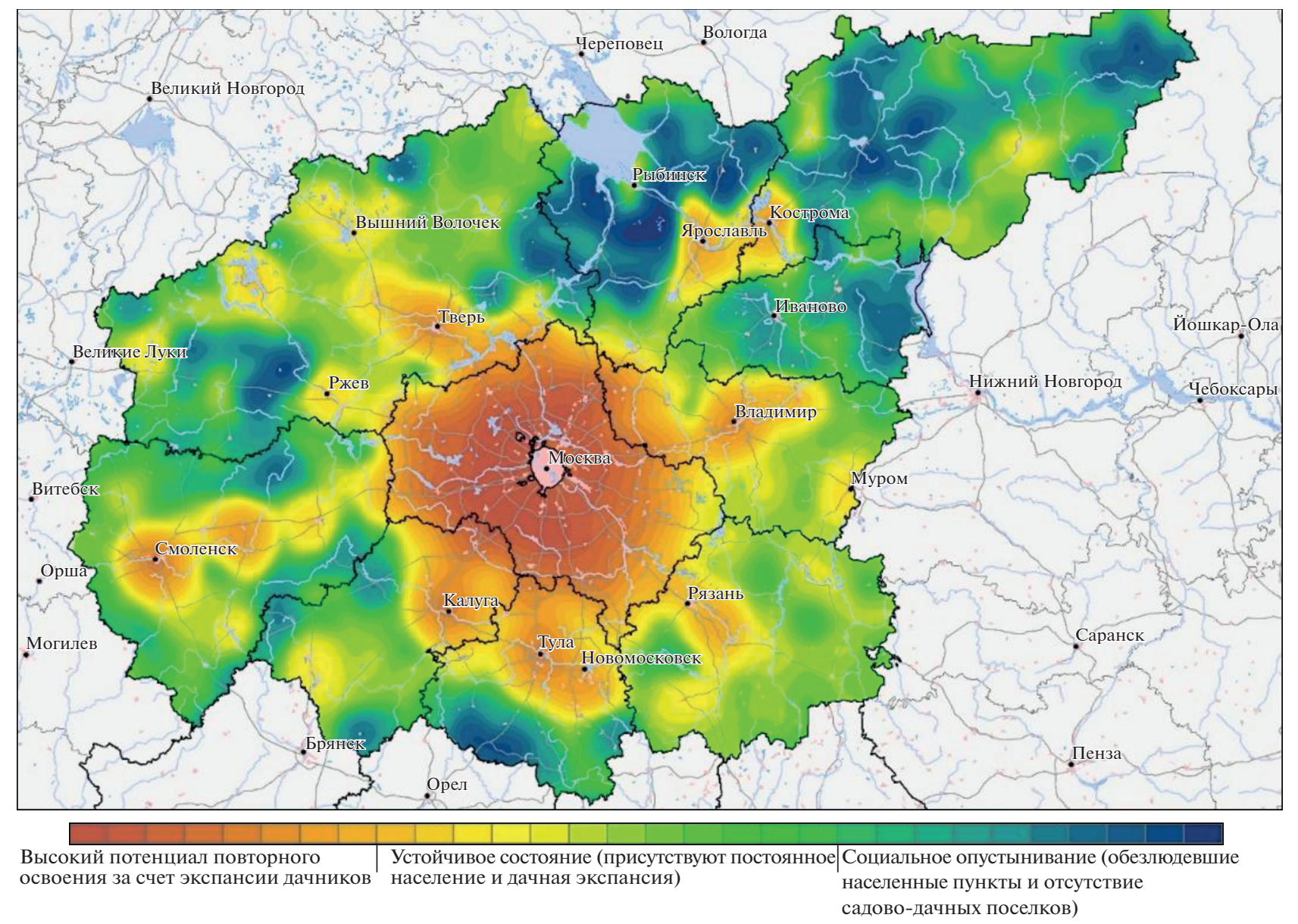

Рис. 11. Зоны потенциального освоения сельской местности горожанами-дачниками и зоны ее возможного социального опустынивания. Составлено А.А. Медведевым.

они были далеки от понимания специфики местной жизни и мало кто добился успеха и задержался надолго. В некоторых местах эта волна сменилась на научно-познавательное отношение горожан к сельской жизни [24]. В последние годы наиболее характерна расширяющаяся рекреационная волна реосвоения с проживанием в деревне от месяца до полугода (в последнем варианте с небольшим огородом) со сбором грибов, ягод, купанием, прогулками в лес и т.п. Круглогодичное проживание встречается редко и характерно в основном для людей пожилого возраста, вынужденных оставить квартиру детям или живущих на доходы от сдачи в аренду городской квартиры. И только единицы пытаются заниматься сельским хозяйством или создавать гостевые дома, что требует энтузиазма и, как правило, использования дополнительных доходов, получаемых за счет основной профессиональной деятельности в городах.

Несмотря на то, что горожане редко занимаются сельским хозяйством, они становятся заметными землепользователями, так как приобретают в собственность вместе с деревенскими домами значительные участки бывших огородов, окружающих деревни, и даже берут дополнительно сельскохозяйственные земли в аренду, отгораживаясь не столько заборами, как в пригородах, сколько пространством. Они пытаются облагораживать эти зарастающие земли, регулярно косят траву, в том числе и для уменьшения пожароопасности. Велико также социальное влияние дачного сообщества на сельскую жизнь. Несмотря на сезонность и относительную кратковременность пребывания, дачники остро нуждаются в рабочей силе для ремонта и обустройства домов, ухода за участками. Они покупают у населения грибы, ягоды, рыбу, молоко. Все это стимулирует новые виды занятости в деревнях и задерживает население. При преобладании в малых деревнях пожилого населения именно горожане-дачники становятся наиболее активной и инициативной группой, заботящейся о сохранении жизнеспособности сельских поселений.

Гораздо более мощным фактором реосвоения и развития сельской местности стало распростра- 
нение садово-дачных и коттеджных поселков [15; 18, с. 362-375]. Садовые и коттеджные поселки, по сути, сформировали вокруг крупных городов мощную параллельную, не учитываемую официальной статистикой, сеть расселения, оказывающую сильное влияние на развитие сельской местности, ее экономику и занятость местного населения. Обычно отдельные садовые и дачные товарищества собраны в пригородах в конгломераты разного объема с населением в летний сезон от нескольких сотен до тысяч человек [31]. Использование космических снимков показало, что, кроме пригородов местных центров, в областях, граничащих с Московской, от 30 до 50\% всех садово-дачных товариществ концентрируется в муниципальных районах, примыкающих к ней. Большая часть рекреационных поселков (от 50 до $70 \%$ ) занимает бывшие сельскохозяйственные земли. Только к северу от Москвы они больше тяготеют к окраинам лесов. Также важно наличие водоемов и расстояние от железной и автомобильных дорог, хотя значимость этих факторов размещения в разных регионах различается.

Ареалы, наиболее перспективные для вторичного рекреационного освоения территории горожанами, показаны на рис. 11. Они выявлены на основе данных космических снимков о локализации садово-дачных и коттеджных поселков и сведений о малых деревнях, потенциально привлекательных для дачников. Учитывались нескольких независимых переменных, таких как удаленность от транспортных магистралей, региональных центров, лесных массивов, а также плотность населенных пунктов с разным статусом. Основная проблема, которая возникала при использовании регрессионного анализа в исследованиях с пространственными данными, - это стационарность регрессионной модели, которая сопровождается возникновением ряда проблем, таких как неустойчивость коэффициентов модели, неправильно вычисленные стандартные ошибки коэффициентов и т.д. [5].

Созданная комплексная модель геоинформационной обработки данных позволила выделить на карте "перспективные" и "неперспективные" зоны дачного реосвоения территории. Помимо пригородных ареалов, уже освоенных дачниками, перспективные территории, в том числе и для дальних дач в деревнях, связаны прежде всего с сочетанием транспортной доступности, водоема и окраин леса. Неперспективные зоны к северу и северо-востоку от Московской области объясняются, помимо слабой транспортной доступности и удаленности, продолжающейся сильной депопуляцией сельской местности, множеством заброшенных деревень и острым недостатком социальной инфраструктуры. На границе Тульской и Орловской областей неперспективная зона обусловлена радиационным загрязнением в результате аварии на Чернобыльской АЭС. Результаты исследования были выборочно проверены во время экспедиционных исследований в ряде районов рассматриваемых регионов.

\section{ЗАКЛЮЧЕНИЕ}

Для современного периода развития сельской местности в Центральной России характерно сжатие освоенного пространства и преобразование крупноареальной системы расселения и землепользования в более очаговую. В связи с этим особенно важным становится понимание, какие очаги могут стать драйверами развития, какая экономика может в них развиваться и что может быть на тех территориях, откуда уходят население и сельское хозяйство.

После длительного сжатия сельскохозяйственного землепользования к пригородам крупных центров к 2010-м годам более явно стали сказываться результаты структурной перестройки сельского хозяйства. Началось частичное возвращение земель в оборот, причем не только в пригородах. А продолжающееся сжатие сельскохозяйственного землепользования стало все больше соответствовать той схеме, по которой оно расширялось в советское время - от староосвоенных очагов с более благоприятными природными предпосылками, только теперь в обратном направлении - к этим очагам. Несмотря на то, что процесс сжатия землепользования в целом активизировался в 1990-х годах, во многом это стало реакцией на действия советских властей, не учитывавших при плановом расширении сельскохозяйственных земель объективные природные, социальные и экономические ограничения. Повышенные затраты в производство с устаревающими технологиями без комплексного социально-экономического развития территории при уменьшении мощной государственной финансовой поддержки в постсоветское время оказались недолговечны. Адаптация сельскохозяйственного производства, с одной стороны, к потребителям, с другой - к природным предпосылкам, указывает на то, что и Россия в целом, и ее центральные регионы проходят тот же путь, который проходили многие страны с развитым агропромышленным комплексом во второй половине $\mathrm{XX}$ в. Однако Россия несколько отстает от современных развитых стран с иновационным развитием АПК и внедрением новейших технологий, способствующих уменьшению влияния на сельское хозяйство биоклиматических условий.

При сохранении существующих тенденций в России роль пригородов в сельском хозяйстве, в том числе Московской области, будет уменьшаться, а роль более южных районов и отдельных очагов с благоприятными природными предпосылками в ближайшее время будет увеличиваться. Это можно увидеть и по значительным площадям необрабатываемых сельскохозяйственных 
земель, часто не фиксируемым официальной статистикой в этом качестве. При неблагоприятных социально-экономических условиях население продолжает концентрироваться в крупных городах и пригородах, тем самым усиливая в Центральной России разрыв между обеспеченностью трудовыми ресурсами, с одной стороны, природными предпосылками и размещением сельскохозяйственного производства - с другой.

При общем сжатии освоенного пространства в регионах вокруг Московской области и сохранении в них экономической активности в отдельных очагах перспективы как ближайших к городам, так и некоторых удаленных районов, связаны с очаговым рекреационно-дачным освоением территорий и деревень. До тех пор, пока в сельских районах не будет соответствующей дорожной и социальной инфраструктуры, они будут привлекать лишь сезонное население и единичных отшельников. Тем не менее это сезонное население может сыграть важную роль в сохранении сети расселения и освоенности территории и, в том числе, дать импульсы малому сельскохозяйственному бизнесу.

Отсутствие информации о реальном сельском расселении и землепользовании с учетом пространственной мобильности населения делает особенно важным применение разнообразных методов исследования, в том числе дешифрирования космических снимков, для выявления степени сельскохозяйственной освоенности и населенности (обжитости) территории. Более того, анализ результатов длительной депопуляции и сжатия сельскохозяйственных земель, с одной стороны, и пространственного размещения факторов, способствующих привлекательности сельской местности для ее рекреационно-дачного реосвоения - с другой, позволяет выявить и показать на картах некоторые перспективы ее развития.

\section{ФИНАНСИРОВАНИЕ}

Исследование выполнено в Институте географии РАН в рамках проекта Российского научного фонда № 19-17-00174 "Развитие районов старого освоения в условиях социально-экономической поляризации и сжатия освоенного пространства Европейской России". Подготовка статистической информации Росстата с 1990 по 2018 г. по муниципальным районам осуществлена Т.Г. Нефедовой и А.В. Шелудковым.

\section{СПИСОК ЛИТЕРАТУРЫ}

1. Аверкиева К.В. Сельская местность Нечерноземья: депопуляция и возможные пути адаптации к новым условиям // Вопросы географии. Сб. 135. География населения и социальная география / Ред. А.И. Алексеев, А.А. Ткаченко. М.: Изд. дом "Кодекс". 2013. С. 108-125.
2. Аверкиева К.В., Нефедова Т.Г. Дачная "колонизация” российской глубинки. Пример Костромской области // Мир России. 2016. № 1. С. 103-128.

3. Алексеев А.И., Воробьев М.И. Сколько сельских жителей в России зимой? // Вестн. Моск. ун-та. Сер. 5: География. 2018. № 2. С. 104-106.

4. Алексеев А.И., Сафронов С.Г. Изменения сельского расселения в России в конце XX - начале XXI в. // Вест. Моск. ун-та. Сер. 5: География. 2015. № 2. C. $66-76$.

5. Балаш В.А., Балаш О.С., Харламов А.В. Особенности построения географически взвешенной регрессии для моделирования рынка недвижимости // Вестн. Саратовского гос. соц.-экон. ун-та. 2008. № 5 (24). C. $125-127$.

6. Буланов К.А., Денисов П.В., Лупян Е.А., Мартьянов А.С., Середа И.И., Трошко К.А., Толпин В.А., Барталев С.А., Хвостиков С.А. Блок работы с данными дистанционного зондирования Земли Единой федеральной информационной системы о землях сельскохозяйственного назначения // Coвременные проблемы дистанционного зондирования Земли из космоса. 2019. Т. 16. № 3. С. 171-182.

7. Глезер О.Б., Вайнберг Э.И. Пространство жизнедеятельности населения и расселение как факторы и условия модернизации России // Регион: экономика и социология. 2013. № 3 (79). С. 21-38.

8. Глобальный климат и почвенный покров России. Опустынивание и деградация земель, институциональные, инфраструктурные, технологические меры адаптации (сельское и лесное хозяйство). Национальный доклад. Т. 2. М.: МБА, 2019. 476 с.

9. Егорова Е.В. Заселенность территории и эффективность использования земельных ресурсов сельских муниципальных образований // Электронный научно-практический журнал “ИнноЦентр”. Вып. № 4 (21). Декабрь 2018. С. 111-117.

10. Зубаревич Н.В. Трансформация сельского расселения и сельской сети услуг в регионах // Изв. РАН. Сер. геогр. 2013. № 3. С. 26-38.

11. Иоффе Г.В., Нефедова Т.Г. Центр и периферия в сельском хозяйстве российских регионов // Проблемы прогнозирования. 2001. № 6. С. 100-110.

12. Казьмин М.A. Земельные реформы в России XIXХХ вв. Уроки пройденного пути. М., 2012. 238 с.

13. Люри Д.И., Горячкин С.В., Караваева Н.А., Денисенко E.A., Нефедова Т.Г. Динамика сельскохозяйственных земель России в XX в. и постагрогенное восстановление растительности. М.: ГЕОС, 2010. 416 с.

14. Лухманов Д.Н. Эволюция сельского расселения // Город и деревня в Европейской России: 100 лет перемен / Под ред. Т. Нефедовой, П. Поляна, А. Трейвиша. М.: О.Г.И., 2001. С. 225-272.

15. Махрова А.Г., Медведев А.А., Нефедова Т.Г. Садоводачные поселки горожан в системе сельского расселения // Вестн. Моск. ун-та. Сер. 5: География. 2016. № 2. C. 64-74.

16. Медведев А.А., Гунько М.С. Выявление признаков наличного населения по материалам дистанционного зондирования // Изв. ВУЗов. Геодезия и аэрофотосъемка. 2016. № 6. С. 85-91.

17. Медведев А.А., Тельнова Н.О., Кудиков А.В. Дистанционный высокодетальный мониторинг динамики зарастания заброшенных сельскохозяйственных земель лесной растительностью // Вопросы лесной науки. 2019. Т. 2. № 3. С. 1-12. 
18. Между домом и ... домом. Возвратная пространственная мобильность населения России / Ред. Т.Г. Нефедовой, К.В. Аверкиевой, А.Г. Махровой М.: Новый Хронограф. 2016. 504 с. http://ekonom.igras.ru/data/bhah2016.pdf

19. Мкрчян Н.В. Миграции в сельской местности России: территориальные различия // Население и экономика. 2019. № 1 (3). С. 39-52.

20. Нефедова Т.Г. Сжатие освоенного пространства России - реальность, а не иллюзия // Сжатие социально-экономического пространства: новое в теории регионального развития и практике его государственного регулирования. М.: Эслан, 2010. C. $128-145$

21. Нефедова Т.Г. Сельская Россия на перепутье. Географические очерки. М.: Новое издательство, 2003. $404 \mathrm{c}$

22. Нефедова Т.Г. Двадцать пять лет постсоветскому сельскому хозяйству России: географические тенденции и противоречия // Изв. РАН. Сер. геогр. 2017. № 5. С. 7-18.

23. Поляризация российского пространства: экономико-, социо- и культурно-географические аспекты. М.: ИП Матушкина, 2018. 416 с.

24. Потенциал Ближнего Севера: экономика, экология, сельские поселения / Под ред. Н.Е. Покровского, Т.Г. Нефедовой. М.: Логос, 2014. 492 с.

25. Румянцев И.Н., Смирнова А.А., Ткаченко А.А. Сельские населенные пункты "без населения" как географический и статистический феномен// Вестн. Моск. ун-та. Сер. 5: География. 2019. № 1. С. 29-27.

26. Сжатие социально-экономического пространства: новое в теории регионального развития и практике его государственного регулирования. М.: Эслан, 2010. $428 \mathrm{c}$.

27. Скобеев Н.М. Новейшие тенденции в изменении землепользования и специфика их учета на примере Тульской области // Региональные исследования. 2017. № 4 (58). С. 81-92.

28. Ткаченко А.А., Смирнов И.П., Смирнова А.А. Трансформация сети центров сельского расселения в низовом районе Центральной России // Вестн. Моск. ун-та. Сер. 5: География. 2019. № 2. С. 78-85.

29. Узун В.Я. “Белые пятна" и неиспользуемые сельхозугодья: что показала сельскохозяйственная перепись 2016 г. // Мониторинг. 2017. № 21 (59). C. $14-21$.

30. Шагайда Н.И., Узун В.Я. Драйверы роста и структурных сдвигов в сельском хозяйстве России. Научн. доклады РАНХиГС. М.: Издат. дом “Дело”, 2019. 96 c.

31. Щепеткова И.О. Территориальная организация садово-дачных образований в пригородах Перми // Изв. РАН. Сер. геогр. 2018. № 4. С. 46-54.
32. Alcantara C., Kuemmerle T., Baumann M., Bragina E.V., Griffiths P., Hostert P., Knorn J., Müller D., Prishchepov A.V., Schierhorn F. Mapping the extent of abandoned farmland in Central and Eastern Europe using MODIS time series satellite data // Environ. Res. Letters. 2013. V. 8. № 3. 035035. https://doi.org/10.1088/1748-9326/8/3/035035

33. Bartalev S., Plotnikov D., and Loupian E. Mapping of arable land in Russia using multi-year time series of MODIS data and the LAGMA classification technique // Remote Sens. Lett. 2016. V. 7. № 3. P. 269-278.

34. Dealing with Urban and Rural Shrinkage / Hospers G.-J., Syssner J. (Eds.). Zurich: Lit Verlag, 2018. 144 p.

35. Hansen M.C., Potapov P.V., Moore R., Hancher M. Turubanova S.A., Tyukavina A., Thau D., Stehman S.V., Goetz S.J., Loveland T.R., et al. High-resolution global maps of 21st-century forest cover change // Science. 2013. V. 342. № 6160. P. 850-853.

36. Kamp J. Land management: Weighing up reuse of Soviet croplands // Nature. 2014. V. 505. № 7484. P. 483.

37. Lesiv M., Schepaschenko D., Moltchanova E., Bun R., Dürauer M., Prishchepov A., Schierhorn F., Estel S., Kuemmerle T., Alcantara C., Concepcion P.C., et al. Spatial distribution of arable and abandoned land across former Soviet Union countries // Scientific Data. 2018. № 5. https://doi.org/10.1038/sdata.2018.56

38. Meyfroidt P., Schierhorn F., Prishchepov A., Müller D., Kuemmerle T. Drivers, constraints, and trade-offs associated with recultivating abandoned cropland in Russia, Ukraine, and Kazakhstan // Global Environ. Change. 2016. V. 37. P. 1-15.

39. Potapov P.V., Turubanova S.A., Tyukavina A., Krylov A.M., McCarty J.L., Radeloff V.C., Hansen M.C. Eastern Europe's forest cover dynamics from 1985 to 2012 quantified from the full Landsat archive // Remote Sens. of Environ. 2014. V. 159. P. 28-43. https://doi.org/10.1016/j.rse.2014.11.027

40. Schepaschenko D., McCallum I., Shvidenko A., Fritz S., Kraxner $F$, Obersteiner $M$. A new hybrid land cover dataset for Russia: A methodology for integrating statistics, remote sensing and in situ information // J. Land Use Sci. 2011. V. 6. № 4. P. 245-259. https://doi.org/10.1080/1747423X.2010.511681

41. Second Home Tourism in Europe: Lifestyle Issues and Policy Responses / Roca Z. (Ed.). Farnham: Ashgate Publishers, 2013. 311 p.

42. Second Home Tourism in Finland / Reports of the Finnish Environ. Institute. 2015. 96 p.

43. The Routledge Handbook of Second Home Tourism and Mobilites / Hall C.M., Muller D.K. (Eds.). London and NY: Routledge, 2018. 365 p.

44. Wegren S.K. Rural inequality in post-Soviet Russia // Problems of Post-Communism. 2014. V. 61 (1). P. 52-64.

\title{
Shrinkage of Active Space in Central Russia: Population Dynamics and Land Use in Countryside
}

\author{
T. G. Nefedova ${ }^{1, *}$ and A. A. Medvedev ${ }^{1, ~ * *}$ \\ ${ }^{1}$ Institute of Geography, Russian Academy of Sciences, Moscow, Russia \\ *e-mail: trene12@yandex.ru \\ **e-mail: medvedev@igras.ru
}

The article is based on a comprehensive approach that includes joint examination of reducing agricultural land, increasing share of small and abandoned villages, and expanding new recreational potential of rural ar- 
eas around Moscow and Moscow oblast. Statistical indicators for Russian federal subjects and municipal districts, as well as satellite images used in the article give a multi-scale and fractional picture of the land use shrinkage which, in recent years, has been more and more clearly repeating the historical process of spatial development, but backwards. Agricultural production is shifting to areas with better natural conditions, including those seen at the intra-regional scale. The trend of concentration in the suburbs, where agriculture takes advantage of accumulated investment, labor resources, sales opportunities, and development of infrastructure, is gradually changing to development in areas with better natural conditions, sometimes remote from cities. At the same time, the population continues to concentrate in large cities and suburbs of regional centers, promoting the shrinkage of populated space. Calculations by municipal districts for the period from 1990 to 2017 confirm these divergent trends. The conclusions are illustrated by maps for the territory of Central Russia, compiled with the help of satellite images that show cultivated and unused agricultural land, as well as the spread of abandoned and small villages. Calculations based on information obtained from maps also allow to adjust the data from statistics and to reveal the real picture of changes in rural settlement and land use. The cartographic method also revealed the possibilities and limitations of re-development of rural areas by city dwellers, including not only expanding areas of garden or dacha associations and cottage settlements, but also single dacha residences in depopulating villages.

Keywords: early developed regions, land use, agriculture, planted area, settlement pattern, population dynamics, re-development, dacha residences, remote sensing, decoding of satellite images, cartographic method

\section{REFERENCES}

1. Averkieva K.V. Rural area of the Non-Chernozem region: depopulation and possible ways of adaptation to new conditions. In Voprosy geografii. Sb. 135: Geografiya naseleniya i sotsial'naya geografiya [Problems of Geography. Vol. 135: Population Geography and Social Geography]. Alekseev A.I., Tkachenko A.A., Eds. Moscow: Kodeks Publ., 2013, pp. 108-125. (In Russ.).

2. Averkieva K.V., Nefedova T.G. Dacha "colonization" of the Russian hinterland. An example of the Kostroma region. Mir Rossii, 2016, no. 1, pp. 103-128. (In Russ.).

3. Alekseev A.I., Vorobiev M.I. How many rural residents are there in Russia in winter? Vest. Mosk. Univ. Ser. 5: Geography, 2018, no. 2, pp. 104-106. (In Russ.).

4. Alekseev A.I., Safronov S.G. Changes in rural settlement in Russia at the end of the XX-beginning of XXI century. Vestn. Mosk. Univ., Ser. 5: Geogr., 2015, no. 2, pp. 66-76. (In Russ.).

5. Balash V.A., Balash O.S., Kharlamov A.V. Features of constructing the geographically weighted regression for modeling the real estate market. Vesn. Saratov. Gos. Sots.-Ekonom. Univ., 2008, no. 5(24), pp. 125-127. (In Russ.).

6. Bulanov K.A., Denisov P.V., Lupian E.A., Martyanov A.S., Sereda I.I., Troshko K.A., Tolpin V.A., Bartalev S.A., Khvostikov S.A. Remote sensing unit of Integrated Federal Information System on agricultural lands. Sovr. Probl. Distantsionnogo Zondirovaniya Zemli iz Kosmosa, 2019, vol. 16, no. 3, pp. 171-182. (In Russ.).

7. Glezer O.B., Vainberg E.I. The space of the life activities of the population and settlement pattern as the factors and conditions of the modernization of Russia. Reg. Res. Russ., 2014, vol. 3, no. 3, pp. 134-140.

8. Global'nyi klimat i pochvennyi pokrov Rossii. Opustynivanie i degradatsiya zemel': institutsional'nye, infrastrukturnye, tekhnologicheskie mery adaptatsii (sel'skoe $i$ lesnoe khozyaistvo [The Global Climate and the Soil Cover of Russia. Desertification and Land Degradation: Institutional, Infrastructural, Technological Adaptation Measures (Agriculture and Forestry)]. Moscow: MBA Publ., 2019, vol. 2. 476 p.
9. Egorova E.V. Settlement patterns of territories and efficiency of land resources use in rural municipalities. Innotsentr, 2018, no. 4(21), pp. 111-117. (In Russ.).

10. Zubarevich N.V. Transformation of the rural settlement pattern and social services network in rural areas. Reg. Res. Russ., 2013, vol. 3, no. 3, pp. 221-233. doi 10.1134/S2079970513030118

11. Ioffe G.V., Nefedova T.G. Center and periphery in agriculture of Russian regions. Probl. Prognozirovaniya, 2001, no. 6, pp. 100-110. (In Russ.).

12. Kaz'min M.A. Zemel'nye reformy $v$ Rossii $v X I X-X X v v$. Uroki proidennogo puti [Land Reforms in Russia in the XIX-XX Centuries. Lessons of the Passed Way]. Moscow: URSS Publ., 2012. 238 p.

13. Lyuri D.I., Goryachkin S.V., Karavaeva N.A., Denisenko E.A., Nefedova T.G. Dinamika sel'skokhozyaistvennykh zemel' Rossii $v$ XX veke i postagrogennoe vosstanovlenie rastitel'nosti $i$ pochv [Dynamics of Agricultural Lands in Russia in XX Century and Postagrogenic Restoration of Vegetation and Soils]. Moscow: GEOS Publ., 2010. 416 p.

14. Lukhmanov D.N. Evolution of rural settlement pattern. In Gorod $i$ derevnya v Evropeiskoi Rossii: 100 let peremen [City and Village in European Russia: 100 Years of Changes]. Nefedova T.G., Polyan P.M., Treivish A.I., Eds. Moscow: OGI Publ., 2001, pp. 225272. (In Russ.).

15. Makhrova A.G., Medvedev A.A., Nefedova T.G. Garden and dacha settlements of citizens in the system of rural settlements. Vestn. Mosk. Univ., Ser. 5: Geogr., 2016, no. 2, pp. 64-74. (In Russ.).

16. Medvedev A.A., Gunko M.S. Identification of the signs of present population based on remote sensing data. $I z v$. Vyssh. Uchebn. Zaved. Geodeziya i Aerofotos'emka, 2016, no. 6, pp. 85-91. (In Russ.).

17. Medvedev A.A., Telnova N.O., Kudikov A.V. Remote highly-detailed monitoring of forest overgrowth on abandoned agricultural lands. Vopr. Lesn. Nauki, 2019, vol. 2, no. 3, pp. 1-12. (In Russ.).

18. Mezrdu domom i ... domom. Vozvratnaya prostranstvennaya mobil'nost naseleniya Rossii [Between Home and ... Home. Return Spatial Mobility of Population in Russia]. Nefedova T.G., Averkieva K.V., Makhrova A.G., Eds. Moscow: Novyi Khronograf Publ., 2016. 504 p. 
19. Mkrtchyan N.V. Migration in rural areas of Russia: territorial differences. Population and Economics, 2019, no. 1 (3), pp. 39-52. doi 10.3897/popecon.3.e34780

20. Nefedova T.G. Shrinkage of the developed space of Russia is a reality, not an illusion. In Szhatie sotsial'noekonomicheskogo prostranstva: novoe v teorii regional'nogo razvitiya $i$ praktike gosudarstvennogo regulirovaniya [Shrinkage of Socio-Economic Space: New in the Theory of Regional Development and Practice of the State Regulation]. Moscow: Eslan Publ., 2010, pp. 128-145. (In Russ.)

21. Nefedova T.G. Sel'skaya Rossiya na pereput'e. Geographicheskie ocherki [Rural Russia at the Crossroads. Geographical Essays]. Moscow: Novoe Izd. Publ., 2003. $404 \mathrm{p}$.

22. Nefedova T.G. Twenty-five years of post-Soviet agriculture in Russia: geographical trends and contradictions. Reg. Res. Russ., 2017, no. 7, pp. 311-321. doi 10.1134/S2079970517040074

23. Polyarizatsiya rossiiskogo prostranstva: ekomoniko-, sotsio- $i$ kul'turno-geograficheskie aspekty [Polarization of the Russian Space: Economic, Socio - Cultural-Geographical Aspects]. Streletsky V.N., Ed. Moscow: IP Matushkina Publ., 2018. 416 p.

24. Potentsial Blizhnego Severa: ekologiya, ekonomika, sel'skie poseleniya [Potential of the Near North: Economy, Ecology, Rural Settlements]. Pokrovsky N.E., Nefedova T.G., Eds. Moscow: Logos Publ., 2014. $492 \mathrm{p}$.

25. Rumyantsev I.N., Smirnova A.A., Tkachenko A.A. Rural settlements "without population" as a geographical and statistical phenomenon. Vestn. Mosk. Univ., Ser. 5: Geogr., 2019, no. 1, pp. 29-27. (In Russ.).

26. Szhatie sotsial'no-ekonomicheskogo prostranstva: novoe v teorii regional'nogo razvitiya i praktike gosudarstvennogo regulirovaniya [Shrinkage of Socio-Economic Space: New in the Theory of Regional Development and Practice of the State Regulation]. Moscow: Eslan, 2010. $428 \mathrm{p}$

27. Skobeev N.M. The latest trends in land use change and the specifics of their accounting on the example of the Tula region. Reg. Issled., 2017, vol. 58, no. 4, pp. 81-92. (In Russ.).

28. Tkachenko A.A., Smirnov I.P., Smirnova A.A. Transformation of the network of rural settlement centers at the lower-level in Central Russia. Vestn. Mosk. Univ., Ser. 5: Geogr., 2019, no. 2, pp. 78-85. (In Russ.).

29. Uzun V.Ya. "White spots" and unused agricultural lands: what the 2016 Agricultural Census showed. Monitoring, 2017, vol. 59, no. 21, pp. 14-21. (In Russ.).

30. Shagaida N.I., Uzun V.Ya. Draivery rosta i strukturnye sdvigi v sel'skom khozyaistve Rossii [Drivers of Growth and Structural Shifts in Russian Agriculture]. Moscow: Delo Publ., 2019. 96 p.

31. Shchepetkova I.O. Dachas in the suburbs of Perm: history, territorial organization, and regional features. Reg.
Res. Russ., 2018, no. 8, pp. 386-394. doi $10.1134 /$ S2079970518040093

32. Alcantara C., Kuemmerle T., Baumann M., Bragina E.V., Griffiths P., Hostert P., Knorn J., Müller D., Prishchepov A.V., Schierhorn F. Mapping the extent of abandoned farmland in Central and Eastern Europe using MODIS time series satellite data. Environ. Res. Lett., 2013, vol. 8, no 3, 035035. doi 10.1088/17489326/8/3/035035

33. Bartalev S., Plotnikov D., Loupian E. Mapping of arable land in Russia using multi-year time series of MODIS data and the LAGMA classification technique. Remote Sens. Lett., 2016, vol. 7, no 3, pp. 269-278.

34. Dealing with Urban and Rural Shrinkage: Formal and Informal Strategies. Hospers G-J, Syssner J., Eds. Münster: LIT Verlag, 2018. 144 p.

35. Hansen M.C., Potapov P.V., Moore R., Hancher M., Turubanova S.A., Tyukavina A., Thau D., Stehman S.V., Goetz S.J., Loveland T.R., et al. High-resolution global maps of 21 st-century forest cover change. Science, 2013, vol. 342, no. 6160, pp. 850-853.

36. Kamp J. Weighing up reuse of Soviet croplands. Nature, 2014, vol. 505, no. 7484, p. 483.

37. Lesiv M., Schepaschenko D., Moltchanova E., Bun R., Dürauer M., Prishchepov A., Schierhorn F., Estel S., Kuemmerle T., Alcantara C., Concepcion P.C., et al. Spatial distribution of arable and abandoned land across former Soviet Union countries. Sci. Data, 2018, no. 5. doi 10.1038/sdata.2018.56

38. Meyfroidt P., Schierhorn F., Prishchepov A., Müller D., Kuemmerle T. Drivers, constraints and trade-offs associated with recultivating abandoned cropland in Russia, Ukraine, and Kazakhstan. Global Environ. Change, 2016. vol. 37, pp. 1-15.

39. Potapov P.V., Turubanova S.A., Tyukavina A., Krylov A.M., McCarty J.L., Radeloff V.C., Hansen M.C. Eastern Europe's forest cover dynamics from 1985 to 2012 quantified from the full Landsat archive. Remote Sens. Environ., 2014, vol. 159, pp. 28-43. doi 10.1016/j.rse.2014.11.027

40. Schepaschenko D., McCallum I., Shvidenko A., Fritz S., Kraxner F., Obersteiner M. A new hybrid land cover dataset for Russia: a methodology for integrating statistics, remote sensing and in situ information. $J$. Land Use Sci., 2011, vol. 6, no. 4, pp. 245-259. doi 10.1080/1747423X.2010.511681

41. Second Home Tourism in Europe: Lifestyle Issues and Policy Responses. Roca Z., Ed. Farnham: Ashgate Publ., 2013. 311 p.

42. Second Home Tourism in Finland: Perceptions of Citizens and Municipalities on the State and Development of Second Home Tourism. Finnish Environ. Inst., 2015. 96 p.

43. The Routledge Handbook of Second Home Tourism and Mobilites. Hall C.M., Muller D.K., Eds. London and N.Y.: Routledge, 2018. 365 p.

44. Wegren S.K. Rural inequality in post-Soviet Russia. Probl. Post-Communism, 2014, no. 61(1), pp. 52-64. 